\title{
Permafrost og klima - om at tage temperaturen på permafrosten
}

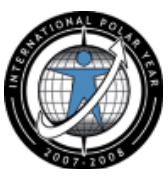

Af Hanne H. Christiansen, Geologisk Avdeling, Universitetssenteret på Svalbard, UNIS \& Institutt for Geofag, Universitetet i Oslo, Norge.

Hvad ved vi egentlig om permafrosten? Når man bor og arbejder året rundt hér i Arktis på Svalbard, lærer man dagligt mere om, hvordan permafrosten og klimaet spiller sammen og udvikler store dele af det flotte arktiske landskab.

\section{Hvad er permafrost?}

I store dele af det arktiske landskab findes permafrost enten meget udbredt eller kun $\mathrm{i}$ få dele af landskabet. Permafrost defineres som permanent frosset sediment eller fjeld, hvor temperaturen ikke har været over $0{ }^{\circ} \mathrm{C}$ $\mathrm{i}$ en mindst 2-årig periode. Dette gør permafrost til en relativt simpel termisk tilstand $\mathrm{i}$ jorden. Et tyndere lag - aktivlaget tør op - og fryser hvert år over permafrosten. Det meste af Jordens permafrost eksisterer således ganske tæt på $0{ }^{\circ} \mathrm{C}$.

I højarktis har toppen af permafrostens temperatur typisk et årsgennemsnit $\mathrm{i}$ intervallet $-15^{\circ} \mathrm{C}$ til $-5^{\circ} \mathrm{C}$, mens den i lavarktis typisk ligger fra $-5^{\circ} \mathrm{C}$ til $0{ }^{\circ} \mathrm{C}$. Derfor kan selv mindre klimatiske variationer påvirke permafrosten specielt i lavarktis, så den øvre del kan tø, den kan blive tyndere eller helt forsvinde, hvor den var tynd i forvejen, og der kan ske ændringer i de landskabsformer, som direkte kontrolleres af permafrosten. Derfor er permafrost et vigtigt forskningsemne.

Permafrost findes i det periglaciale miljø, dvs. i landskaber hvor fryse-tø-processer dominerer, og hvor årsmiddellufttemperaturen typisk er lidt under ca. $3{ }^{\circ} \mathrm{C}$. Sådanne områder ligger typisk over trægrænsen $\mathrm{i}$ alpine områder eller udgør hele eller dele af landskabet i de arktiske egne uden for de gletscherdækkede områder.

Hvis årsgennemsnitslufttemperaturen ligger under $-1{ }^{\circ} \mathrm{C}$ til $-2{ }^{\circ} \mathrm{C}$, er der højest sandsynligt permafrost $\mathrm{i}$ dele af det periglaciale landskab. Permafrost findes i dag i ca. $25 \%$ af Jordens terrestriske dele, primært på den nordlige halvkugle, hvor der er størst landmasse (figuren ovenfor). Under sidste istid fandtes permafrost $i$ store dele af Europa helt ned mod Middelhavet og gene-
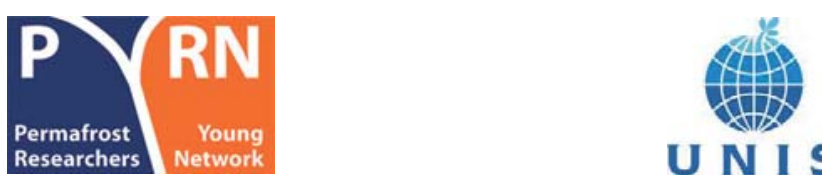

U N I S

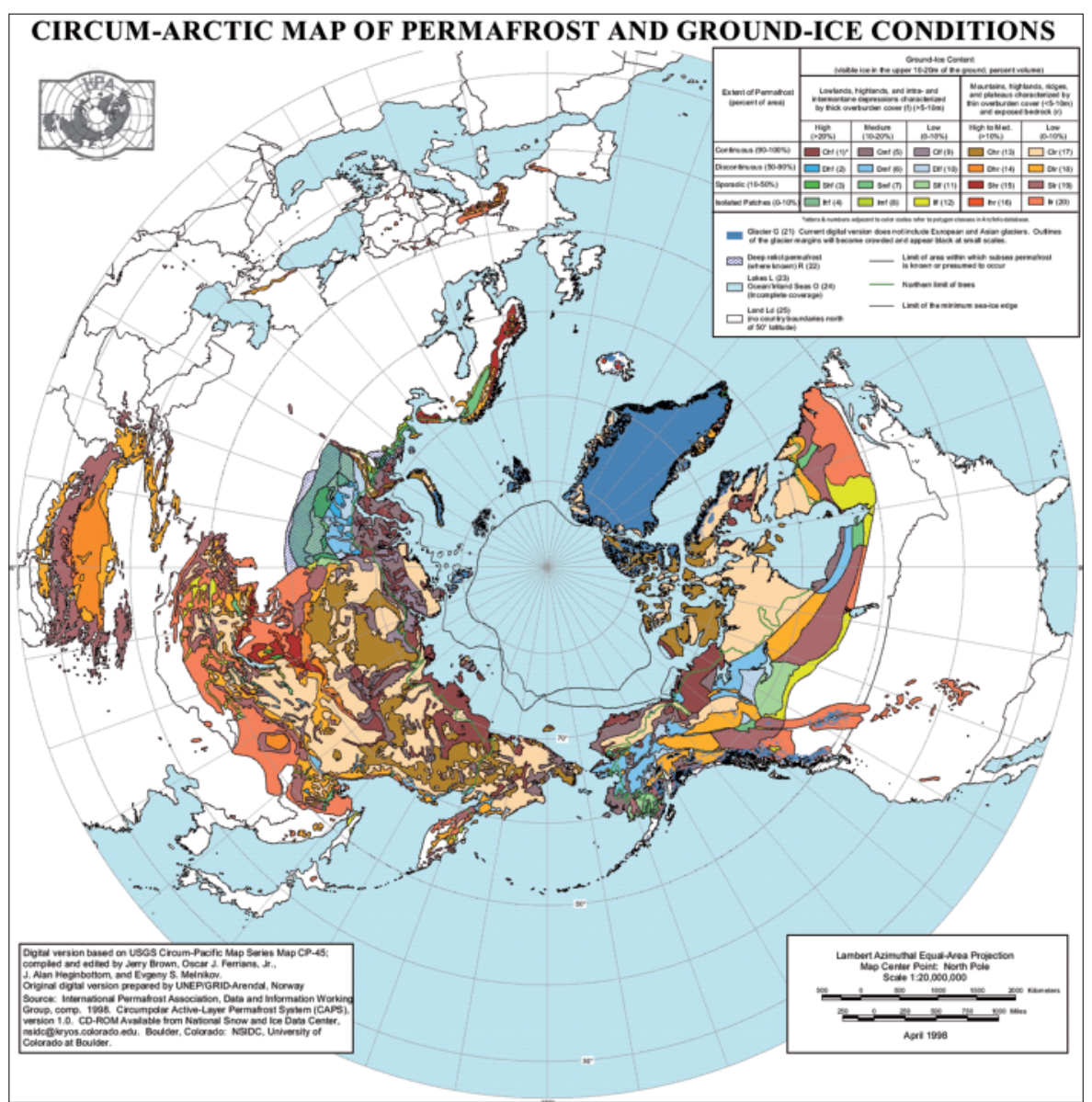

Permafrostkort IPA. Udbredelsen af permafrost på den nordlige halvkugle. Farverne viser de forskellige typer af permafrost fra kontinuerlig (mørkebrune farver), diskontinuerlig (lyseblå farver) til sporadisk (grønlige farver). Farvenuancerne viser således forskelle $i$ isindhold. (Kilde Brown et al., 1998. Circumpolar Active-Layer Permafrost System (CAPS) vers 1.0. 1998. Available from the National Snow and Ice Data Center, University of Colerado, Boulder, USA)

relt i ca. $50 \%$ af de ikke-gletscherdækkede landområder.

Kan permafrost påvirke klimaet eller...? Permafrost er en vigtig, men hidtil ofte mindre omtalt del af kryosfæren. Dette skyldes nok primært, at permafrost kun sjældent ses synligt i landskabet, med mindre man kender de specielle landskabsformer, som skabes $i$ områder med permafrost. I den senere tid er permafrost blevet mere omtalt i klimadebatten pga. muligheden for øget frigivelse af kuldioxid $\mathrm{CO}_{2}$, metan $\mathrm{CH}_{4}$ og andre drivhusgasser fra optøende permafrost, hér specielt meget organisk rig permafrost som i moser og tundraområder. Dvs. at permafrosten direkte vil kunne påvirke klimaets udvikling.
Et andet centralt spørgsmål i klimaforskningen vedrørende permafrost, som man ofte hører stillet, er, om der ikke er en entydig sammenhæng mellem luftens og jordens temperatur? Altså således at hvis lufttemperaturen stiger, så stiger også temperaturen i jorden. Med andre ord om luftens temperatur direkte afspejles i jordens temperatur? Så simple er forholdene imidlertid ikke, idet vi ved, at sammenhængen mellem klima og permafrost er mere kompleks, da flere klimatiske og ikke-klimatiske faktorer kontrollerer permafrostens temperatur. Nedbørsmængde - primært i form af sne og hér både varighed og hvornår sneen falder - er vigtig. Jo længere og tykkere snedække jo "varmere" permafrost. Også vinden er vigtig, 
fordi den kan blæse sne væk og tillade bedre afkøling af jorden, eller føre til ophobning af snedriver i lælommer i landskabet, som så kan føre til højere temperatur i jorden.

Lokalt i landskabet styres permafrostens temperatur desuden i høj grad af flere lokale faktorer som topografi, type og højde af vegetation, og af om permafrosten findes $i$ sediment eller fjeld. Vegetation kan føre til lokal opvarmning, og hvis den er høj, give et tykkere snelag, omvendt kan et højt tørveindhold føre til øget afkøling om vinteren og mindre opvarming om sommeren pga. specielle termiske egenskaber. Hvis permafrost findes i fjeldet, er det oftere mindre isholdigt og kan derfor hurtigere respondere på klimatiske variationer, mens isrig permafrost i sedimenter har meget længere responstid på opvarmning, fordi der skal meget mere energi til at tø isen op.

Over længere tid og over større områder, dvs. både geologisk og geografisk set, er det klimaet, som bestemmer udbredelsen af permafrost.

Den tykkeste permafrost findes i dag i Sibirien, hvor der under sidste istid var for tørt til, at gletschere kunne eksistere. Derfor afkøledes jorden kraftigt, og tyk permafrost udviklede sig. I dag er permafrosten stadig ganske tyk i dette område - op til $1.600 \mathrm{~m}$, hvilket vidner om den effektive afkøling under sidste istid; og at det tager lang tid og meget energi at optø så dyb permafrost. $\mathrm{Nu}$ er gammel permafrost også fundet $i$ havbunden nord for Rusland, som et vidnesbyrd om permafrostens udbredelse under istider med lavere global havvandstand.

\section{Permafrost i Norden}

Norden er det mindst udforskede område mht. permafrost og periglacial geomorfologi i Arktis. Dette hænger naturligvis sammen med den meget mindre udbredelse af permafrost her sammenlignet med $i$ andre dele af Arktis (figuren på foregående side). Der er en meget længere forskningstradition $i$ Rusland, Canada og Alaska samt Kina, hvor man i dag har op til 20-30-årige temperaturserier fra permafrosten, samt detaljerede regionale kort over permafrostens udbredelse og isindhold. Dette er meget værdifuldt for nærmere at kunne studere, hvilke klimatiske og lokale faktorer som har størst indflydelse på permafrostens temperaturudvikling.

I Norden har vi alle typer permafrost tilstede inden for relativt korte afstande. Der er permafrost i hele landskabet på Svalbard uden for de gletscherdækkede områder, dette kaldes kontinuerlig permafrost. I Norge, Sverige og Finland findes permafrost primært i de højereliggende fjelde, og den er ofte ikke sammenhængende, dette kaldes diskontinuerlig permafrost. Permafrost findes også i enkelte landskabsformer længere nede i landskabet, og er såkaldt sporadisk. Grønland har også kontinuerlig permafrost i store dele af landskabet i hele den nordlige halvdel/randzone af landet uden for

Oversigtskort over permafrost-borehullernes placering på Nordenskioldland, Svalbard. (Grafik: Markus Eckerstorfer og Håvard Juliussen, UNIS)

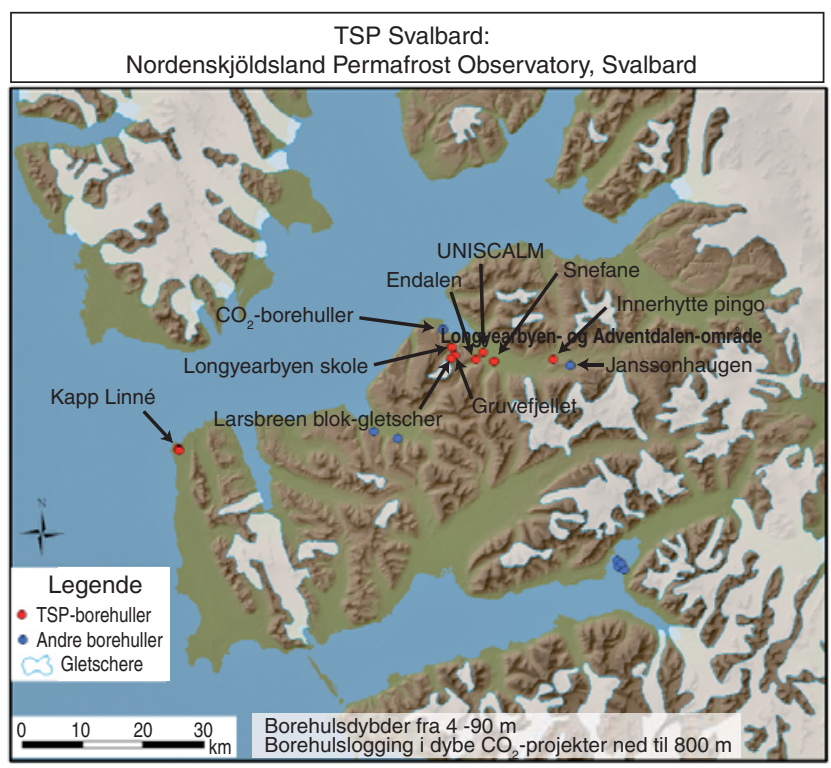

Indlandsisen, mens der findes alle typer permafrost $i$ den sydlige halvdel ofte med en højdemæssigt kontrolleret fordeling. På Island findes permafrost i mindre områder i fjeldene. Der findes ikke naturlig permafrost i det danske landskab, men under sidste istid var der permafrost i de ikke-gletscherdækkede områder.

I Norden har vi endnu ikke nogen detaljeret kortlægning af permafrostens udbredelse, og det eneste kort, der findes, er det cirkumpolare permafrostkort (figuren på side 4). Et bredere samarbejde om permafrostforskning er nu begyndt. Under det Internationale Polarår (IPY) 2007-2009 har der været stor aktivitet i Norge, nogen aktivitet i Sverige og Grønland, samt lidt i Finland og Island.

I 2010 afholdes for første gang europæisk permafrostkonference i Norden, på Svalbard, hvor vi bl.a. skal vise permafrost-forskningsinstallationer frem etableret under IPY.

\section{Permafrost-observatorier}

For at kunne studere, hvad der kontrollerer permafrostens termale tilstand og dermed også aktivlagets tykkelse, har vi i det Internationale Polarårs forskningsprojekt "Permafrost Observatory Project: A Contribution to the Thermal State of Permafrost" (TSP) etableret en række borehuller ned i permafrosten forskellige steder - primært i Arktis,
Permafrost kommer blasende op under boring med Sintefs hammerborerig under ledelse af Jomar Finseth $i$ april 2008 i en pingo $i$ Adventdalen, Svalbard. (Foto: Hanne H. Christiansen)

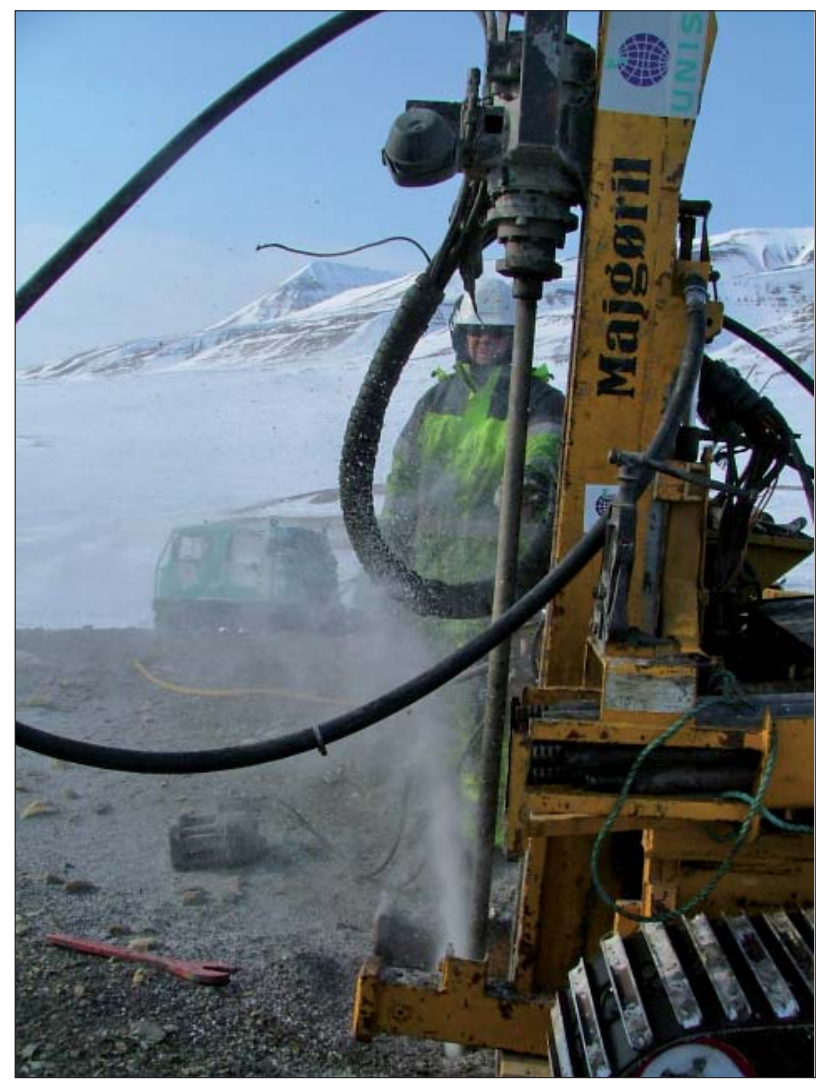


men også i Antarktis. Der har været aktivitet i nationale TSP-projekter i både Alaska,

Rusland, Canada og Norge samt generelt $\mathrm{i}$ nordiske samarbejdsprojekter. Der har været størst fokus i TSP-projektet på direkte at måle permafrostens temperatur i borehullerne og således få et snapshot af permafrostens termale tilstand under IPY i så mange forskellige dele af landskabet som muligt.

For at kunne gøre det har vi boret flere huller ned til mellem 10 og 100 meters dybde i forskellige landskabsformer og i forskellige højder over havet. På Svalbard i TSP NORWAY-forskningsprojektet har vi boret og etableret måleudstyr i 15 nye borehuller (figuren øverst på side 5). De fleste af disse borehuller er placeret i forskellige permafrostlandskabsformer i og omkring Longyearbyen, men også på vestkysten af Svalbard ved Kapp Linné, som er det mest maritime sted på Svalbard. Vi har boret ned i blokmark (område dækket med kantede sten og blokke dannet som følge af mekanisk nedbrydning af klipper pga. frostsprængning), blokgletschere (foto på side 9), solifluktionslober (flydejord på hældende terræn dannet ved frosthævning og optøning af det øverste jordlag (aktivlaget) om sommeren), løss-terrasse (vindaflejret finkornet sediment), iskile (forsidefoto), oven for og under tyk snedrive, i braideret flodslette (smeltevandsslette med et flettet flodsystem), pingo (foto nederst på side 8), iskernemoræne (gletscheraflejring med en indre kerne af gletscheris), nunatak (klippetop, der stikker op over en omgivende gletscher) og strandflade. Nogen borehuller ligger i fjeld, mens andre er i sedimenter.

De fleste huller er lavet med en hammerborerig (foto nederst på side 5). Ved denne metode blæses materialet op fra borehullet med trykluft. Andre steder har vi lavet kortere håndboringer, hvor vi har indsamlet borekerner fra permafrostens top typisk ned til ca. 3 m's dybde (foto ovenfor). På et særligt permafrost-universitetskursus under IPY, hvor vi sammenlignede permafrosten på Svalbard og NØ-Grønland, indsamlede 10 studenter og 2 lærere mere end $25 \mathrm{~m}$ kerner fra 13 borehuller.

Umiddelbart efter et borehul er færdigt, sættes et plastrør, lukket i nedre ende, ned i borehullet. Inden i dette rør installerer man så en temperaturstreng med tilhørende datalogger (foto nederst på denne side), således at temperaturen kan måles i forskellige dybder i hele borehullets længde, og lagres

\section{God net-adresse}

NORPERM, den første norske permafrostdatabase, hvor man bl.a. kan finde links til Svalbard og Norge på:

www.tspnorway.com

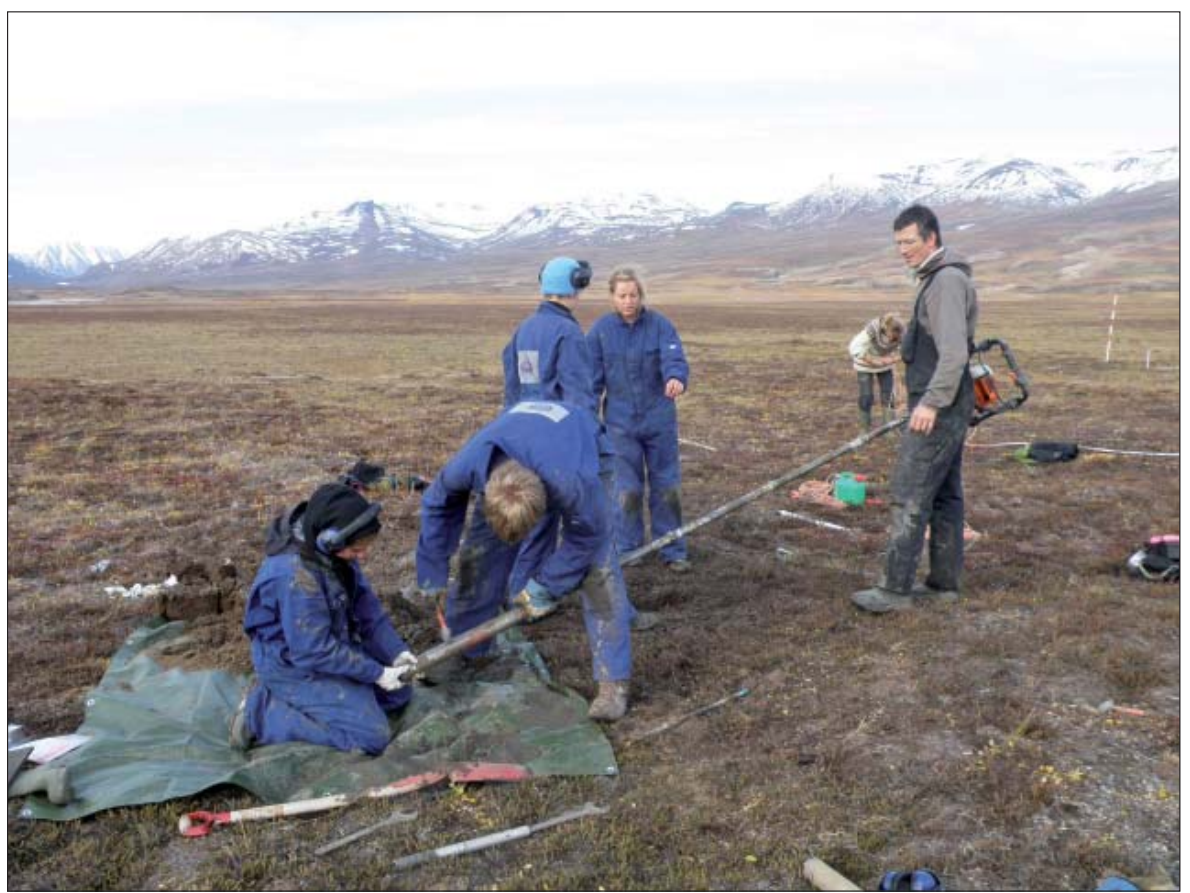

Et hold UNIS-studenter håndborer en $3 \mathrm{~m}$ lang permafrost kerne op i Zackenberg, NØ-Grønland, sammen med Bo Elberling, Institut for Geografi og Geologi, Københavns Universitet \& UNIS. (Foto: Hanne H. Christiansen)

vedvarende. Vi har således dataloggere med op til 25 temperatursensorer i varierende dybder i vores forskellige borehuller på Svalbard. De registrerer temperaturen enten en gang i timen eller hver 6 . time.

De etablerede borehuller er således samlet i regionale, geografisk afgrænsede observatorier. På Svalbard ligger alle de nye permafrost-installationer på halvøen
Nordenskiöldsland og udgør nu Nordenskiöldsland Permafrost Observatory. I andre dele af Arktis findes lignende regionale permafrost-observatorier ofte med N-S eller Ø-V udstrækning på tværs af klimatiske gradienter.

NORPERM - norsk permafrostdatabase Som noget nyt i Europa under IPY har man

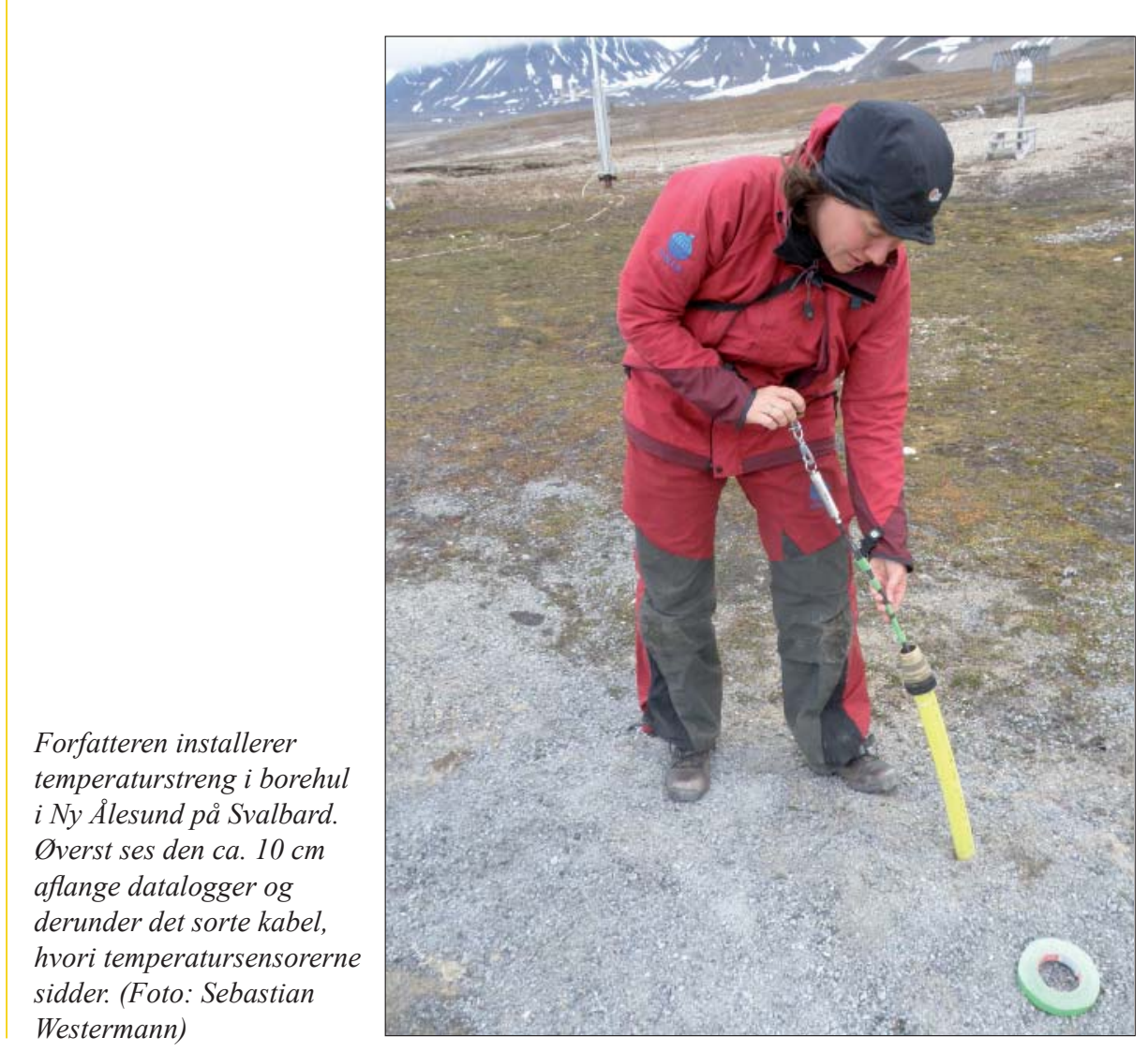


helt åben datapolitik. Således er alle IPYprojekter forpligtet til at gøre forskningsdata tilgængelige også for ikke-projektdeltagere. Data lægges ind i offentligt tilgængelige databaser og dermed sikres det, at data kan gå direkte videre $\mathrm{i}$ arv til næste generation af forskere. Dette gøres således for at sikre, at bl.a. de indsamlede permafrostdata bliver en vigtig del af arven fra IPY 2007-2009.

I Norge har vi etableret den første norske permafrostdatabase som en del af TSP Norway-projektet. Den hedder NORPERM og ligger rent fysisk hos Norges Geologiske Undersøkelse, NGU, hvor den er en del af den samlede borehulsdatabase (se net-adressen i boksen).

Internationalt har vi en samlet permafrost-database "Global Terrestrial Network on Permafrost" (GTN-P), som huses ved Geological Survey of Canada, og som primært indeholder borehulsdata, men også aktivlags tykkelsesdata.

\section{Permafrosttemperaturer 2008-2009}

Vi har høstet det første hele års temperaturdata fra alle TSP Norway-borehullene på Svalbard sidst på sommeren 2009. Figuren øverst på denne side viser et overblik over temperaturforholdene to steder på Svalbard. Det ene er fra permafrosten ned til 19 m's dybde i et af TSP NORWAY-borehullerne gennem et solifluktionslag og videre ned $i$ det faste fjeld i 6 m's dybde i Endalen ca. 4 $\mathrm{km} ø$ øst for Longyearbyen.

Det andet er fra et $10 \mathrm{~m}$-borehul ca. 500 $\mathrm{m}$ fra Endalen-borehullet på en løss-terrasse centralt i Adventdalen. Som det ses, er der størst årstemperaturvariation i aktivlaget og den øverste del af permafrosten, mens der knapt er nogen årsvariation under 10-12 m's dybde. Dette viser, at den årlige temperaturvariation ikke trænger længere ned end til 10 m's dybde. Under denne dybde vil temperaturen stige svagt med dybden, på grund af varmeafgivelse fra Jordens kerne. Men hvis et område har haft klimavariationer, vil disse findes som bølger på temperaturkurven under dybden for den årlige variation. Man ser også, at permafrosten i Adventdalen ligger på $-5^{\circ} \mathrm{C}$, noget som generelt er koldere end i de fleste andre dele af landskabet, hvor vi måler permafrostens temperatur på Svalbard ved havniveau som fx Endalen, hvor permafrosttemperaturen kun er omkring $-3^{\circ} \mathrm{C}$.

Skulle du have lyst at se, hvordan temperaturen er lige nu i permafrosten i Endalen på Svalbard, er det bare at kigge med på www.unis.no under "weather stations". Vi har også et andet borehul online. Det ligger i blokmark og fjeld på Gruvefjellet lige over Longyearbyen. Det er Universitetssenteret på Svalbard, UNIS og Permafrost Young Researchers Network, PYRN, som har besluttet at lave direkte adgang til permafrosttemperaturer fra Svalbard fra disse to borehuller. Og du kan også direkte hente data fra samme websites.

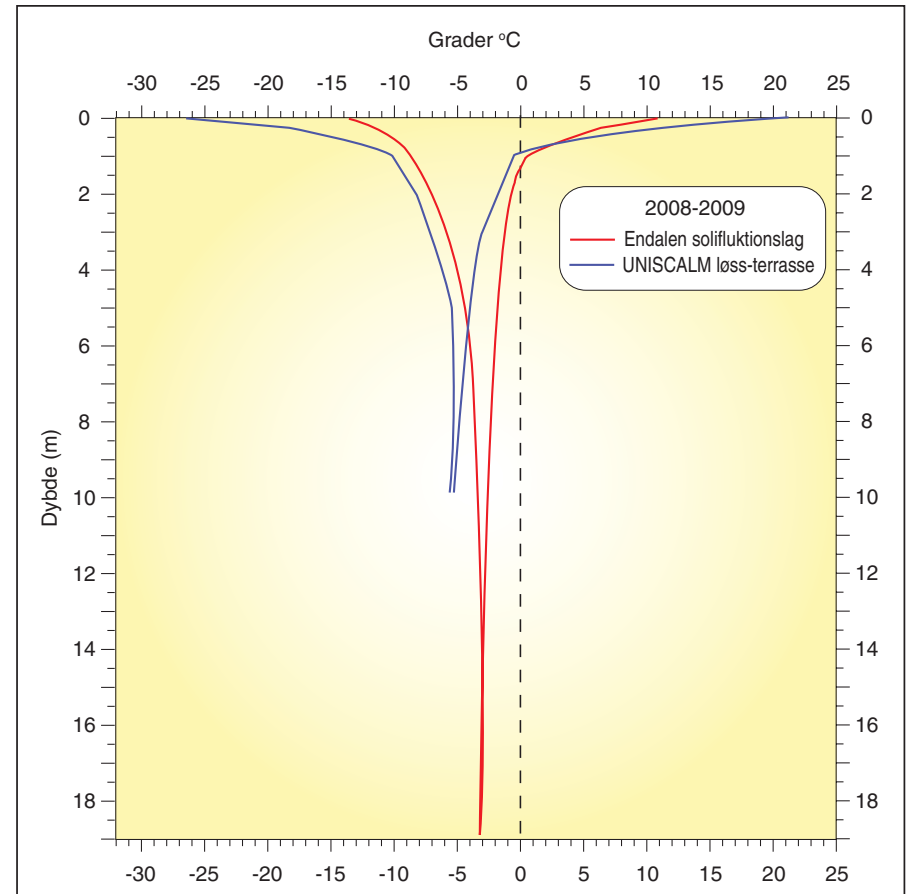

\section{Aktivlagets tykkelse}

En anden vigtig del af permafrost - klimasammenhængen - er den direkte måling af tykkelsen af aktivlaget. Denne viser, om toppen af permafrosten tør. I Circumpolar Active Layer Monitoring Network (CALM) -samarbejdet, måles aktivlagets tykkelse sidst på sommeren mere end 150 steder, primært i forskellige dele af Arktis. Typisk måler man hvert sted $i$ et fast markeret net med 121 målepunkter og en maskestørrelse på fra $10 \times 10 \mathrm{~m}$ til $1.000 \times 1.000 \mathrm{~m}$. På Svalbard har vi indsamlet data i UNISCALM-målenettet siden år 2000. Dette sted ligger på en løss-terrasse, og de finkornede sedimenter muliggør direkte måling af tykkelse af aktivlaget.

Målingene foretages som dybdemålinger med et spyd direkte ned til permafrostens top og foregår sidst på sommeren typisk sidst $\mathrm{i}$ august eller midt i september, umiddelbart inden aktivlaget begynder at fryse igen.

På Svalbard laver vi CALM-målinger igennem hele optøningsperioden typisk fra maj til september, da vi jo bor og arbejder her oppe året rundt. Derved er vi sikre på, hvornår vi har den maksimale optøning og kan følge variationer mellem somrenes optøningsforløb for at studere, hvilke meteorologiske parametre som forårsager dette. Som det ses på figuren nedenfor, varierer tykkelsen af aktivlaget mellem årene, og den har således i de sidste 10 år ligget mellem $74 \mathrm{~cm}$ og $110 \mathrm{~cm}$. Specielt de sidste par somre har optøningen været lidt dybere.

\section{Permafrostlandskabsformer}

Kender man det periglaciale landskab godt, kan man direkte se en række landskabsformer, som skabes af permafrost. Der findes

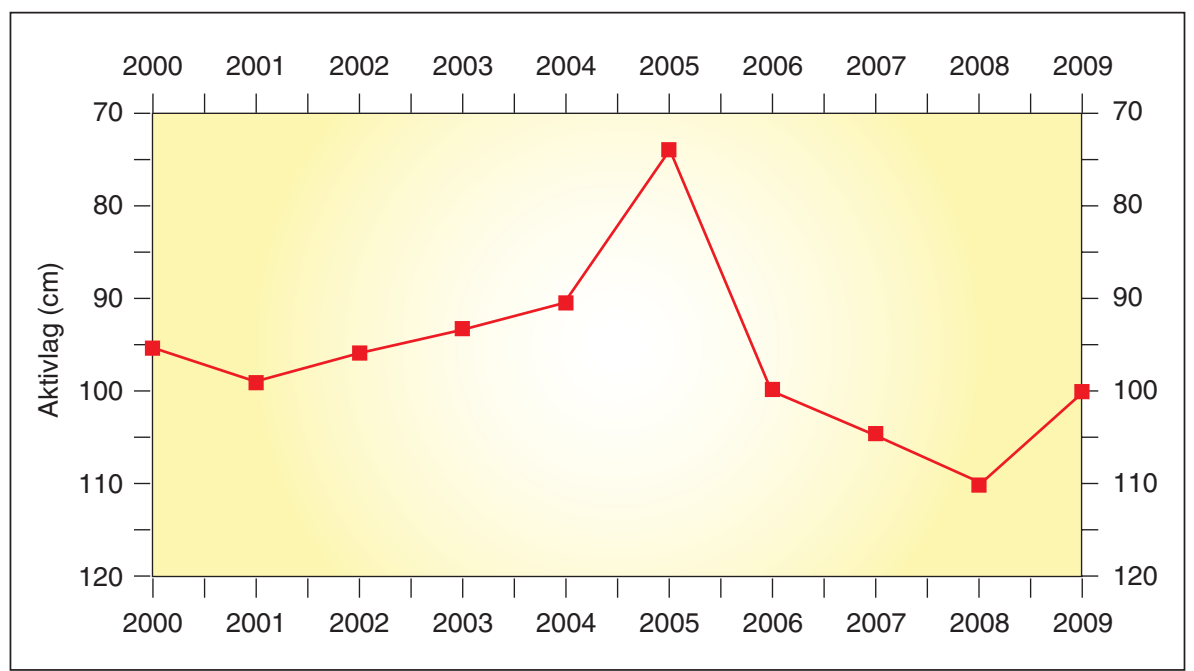

Gennemsnitlig optøningsdybde i det $100 \times 100 \mathrm{~m}$ store UNISCALM-felt, hvor hver måling er et gennemsnit af de 121 punkter i feltet. (Grafik: UVH modificeret efter Hanne H. Christiansens forskningsdata) 
flere flotte og spændende periglaciale landskabsformer, som kun kan udvikles og være aktive, hvor der findes permafrost. Hvis man kender disse landskabsformer, kan man således kortlægge udbredelsen af permafrost $i$ et område nærmere.

En af de mest udbredte permafrostbetingede landskabsformer i lavlandsområder er iskile-polygoner (se forsiden). Disse findes primært i kontinuerlige permafrostområder og dannes, når jorden trækker sig sammen ved afkøling om vinteren. Typisk ved bratte temperaturfald ned til lufttemperaturer under $-20{ }^{\circ} \mathrm{C}$ kan der åbnes en revne nede i iskiletruget, som viser, at det frosne aktivlag er trukket fra hinanden lige over iskilen.

I Danmark kan man i grusgrave finde rester efter iskiler bevaret som såkaldte iskileafstøbninger, det vil sige former, hvor sedimentet er flydt ned og har udfyldt den plads, som isen havde, da permafrosten stadig eksisterede, og iskilen var aktiv. Det interessante er, at på Svalbard i dag ser vi aktive iskiler, selvom gennemsnitslufttemperaturen er så høj som $-2{ }^{\circ} \mathrm{C}$ til $-4{ }^{\circ} \mathrm{C}$. Det er imidlertid ikke gennemsnitstemperaturen, som er interessant $\mathrm{i}$ denne sammenhæng, men derimod om der findes stabile kolde vinterperioder, typisk når vi har højtryk.

Pingoer er en anden iøjnefaldende periglacial landskabsform, som betyder "bakke med iskerne". Altså skal der være permafrost tilstede, for at de kan dannes. Pingoer opstår, når der er tilstrømning af vand ind $\mathrm{i}$ permafrosten, hvor vandet så fryser, og en iskerne dannes, og hvor jordoverfladen lokalt løftes op i en 10-30 m høj bakke typisk med stejle sider. For det meste ligger sådanne pingoer nede i landskabet (foto øverst på denne side), hvorved det tilstrømmende vand kan komme under højt nok tryk til at kunne presse sig vej op i permafrosten. Oftest kender man ikke helt nøjagtigt til, hvor vandet kommer fra. Det kan komme fra en ufrossen zone under en tykkere gletscher, eller det kan komme langs med forkastninger. Pingoer vidner således om, at der kan være svaghedszoner i permafrosten, hvor man selv på en dag med lufttemperatur på $-16^{\circ} \mathrm{C}$ kan se vand komme op og fryse hurtigt på overfladen (foto nederst på denne side). Som regel findes ganske lave temperaturer i permafrosten i pingoer, da de ofte ligger blæst fri for sne i store dele af vinteren.

På fjeldsider med permafrost og foran visse gletschere kan man ofte finde blokgletschere (foto på næste side), som ligner stendækkede gletschere. Sædvanligvis er blokgletscherens overflade dækket af meget store blokke. Disse dannes ved frostforvitring $\mathrm{i}$ fjeldsiden og transporteres derfra og nedover i landskabet, langsomt ved deformation og krybning i permafrosten inde $\mathrm{i}$ blokgletscheren frem til den ofte relativt stejle front af blokgletscheren. Blokgletscheren vil være i bevægelse, så længe der er permafrost tilstede, således at is kan krybe og derved transportere blokkene.

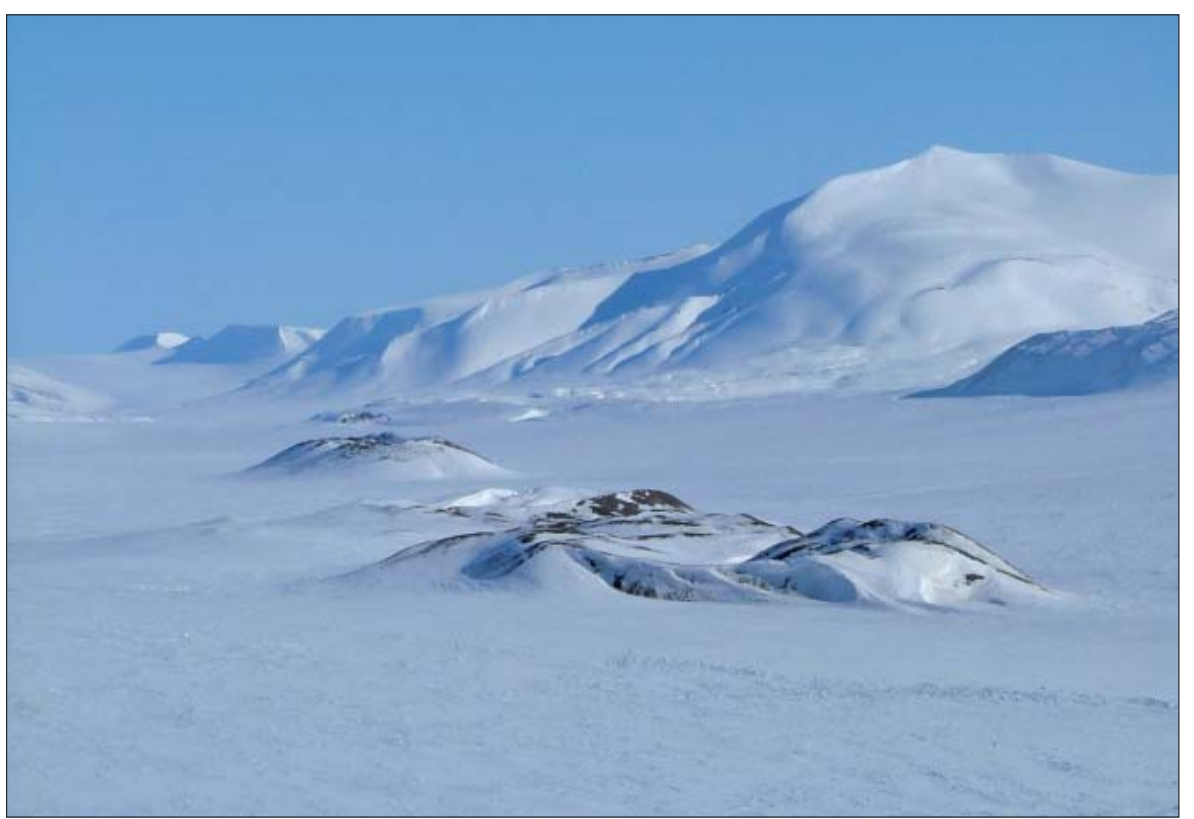

Fire pingoer ligger som perler på en snor nede i Reindalen på Svalbard. De er på forskellige udviklingsstadier. (Foto: Hanne H. Christiansen)
Dette kaldes en aktiv blokgletscher. Hvis permafrosten forsvinder helt pga. opvarmning, vil blokgletscheren ligge stille, og ikke have en så stejl front, som når den er aktiv. Man kan derfor ofte afgøre, om en blokgletscher er aktiv eller ej, hvis man prøver at gå op ad dens front. Det er i øvrigt ikke særligt let eller klogt at gå op ad en aktiv blokgletschers front.

\section{At finde permafrost}

Næste gang, du er på tur i vores flotte kolde nordiske landskaber, er det muligt du genkender en periglacial landskabsform, og hvis den så oven i købet kræver permafrost for at kunne dannes, ja så har du fundet den ofte lidt skjulte permafrost. Vi søger stadig efter en bedre forståelse for, hvor præcist permafrosten befinder sig i store dele af det nordiske landskab, så det er stadig muligt at gøre ny fund.

\section{Tak}

En stor tak til alle mine norske, danske og internationale kolleger, som jeg har arbejdet sammen med under IPY med permafrostforskningen og til min fantastiske arbejdsplads, Universitetssenteret på Svalbard, UNIS, som gør det muligt dagligt at loere nyt

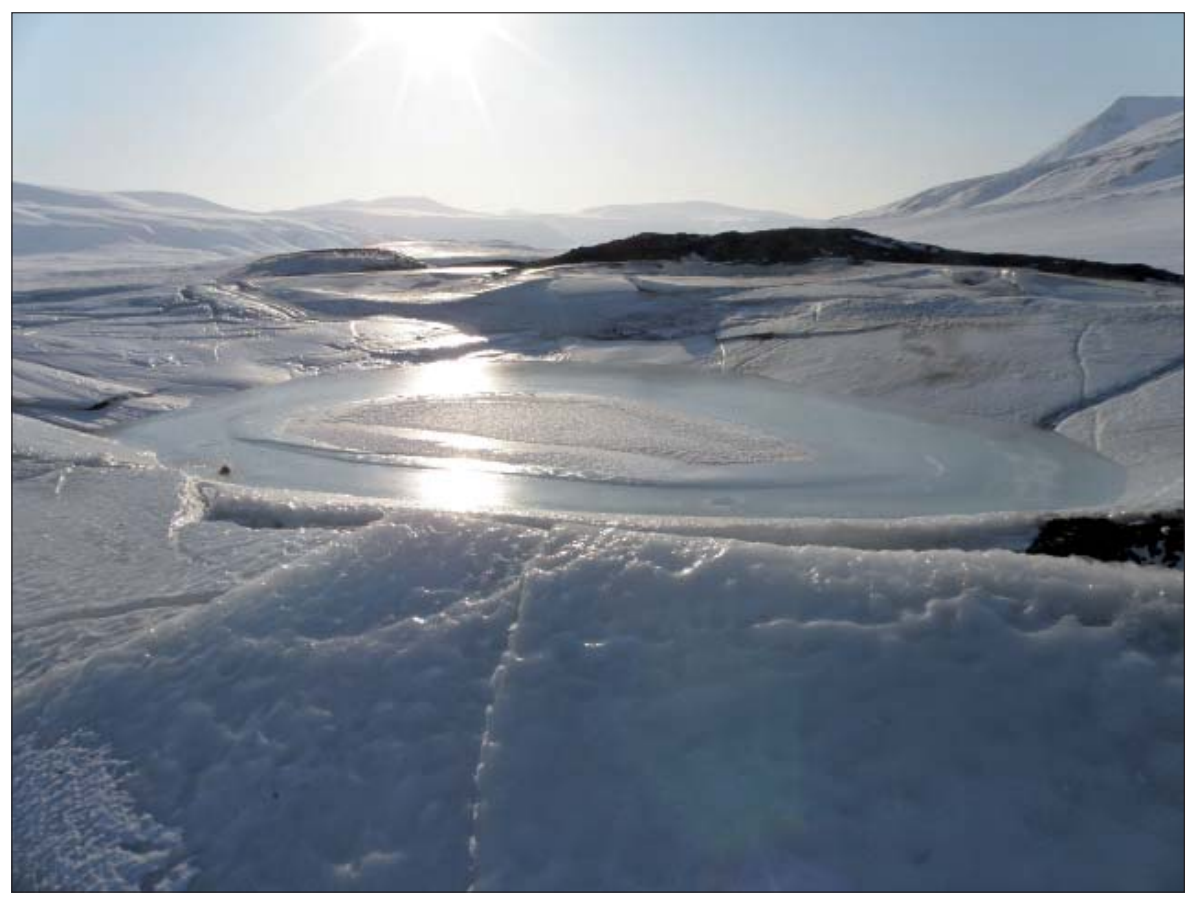

Vand trcenger op til toppen af en pingo i Adventdalen på Svalbard i april 2009 og den lille sø (ca. $4 \mathrm{~m}$ i diamenter) genfryser hurtigt. (Foto: Hanne H. Christiansen) 
om permafrosten her på Svalbard.

\section{Anbefalet litteratur:}

Christiansen HH. Humlum O. 2008. Interannual Variations in Active Layer Thickness in Svalbard. In Kane, D.L. \& Hinkel, K.M (eds.) Ninth International Conference on Permafrost Proceedings, Institute of Northern Engineering, University of Alaska, Fairbanks, USA, 257-262.

Harris $C$, Arenson LU, Christiansen $\mathrm{HH}$, Etzelmüller B, Frauenfelder R, Gruber $S$, Haeberli W, Hauck C, Hölzle M, Humlum $O$, Isaksen K, Kääb A, Kern-Lütschg MA, Lehning M, Matsuoka N, Murton JB, Nötzli J, Phillips M, Ross N, Seppälä M, Springman SM, Vonder Mühll D. 2009. Permafrost and climate in Europe: Monitoring and modelling thermal, geomorphological and geotechnical responses. Earth Science Reviews, 92: 117-171.

Humlum O, Instanes A, Sollid JL. 2003.

Permafrost in Svalbard: a review of research history, climatic background and engineering challenges. Polar

Research, 22: 191-215.

H.M. French. 2007. The Periglacial Enviroment, Wiley, third edition, $458 \mathrm{~s}$.

Anbefalede websider:

International Permafrost Association:

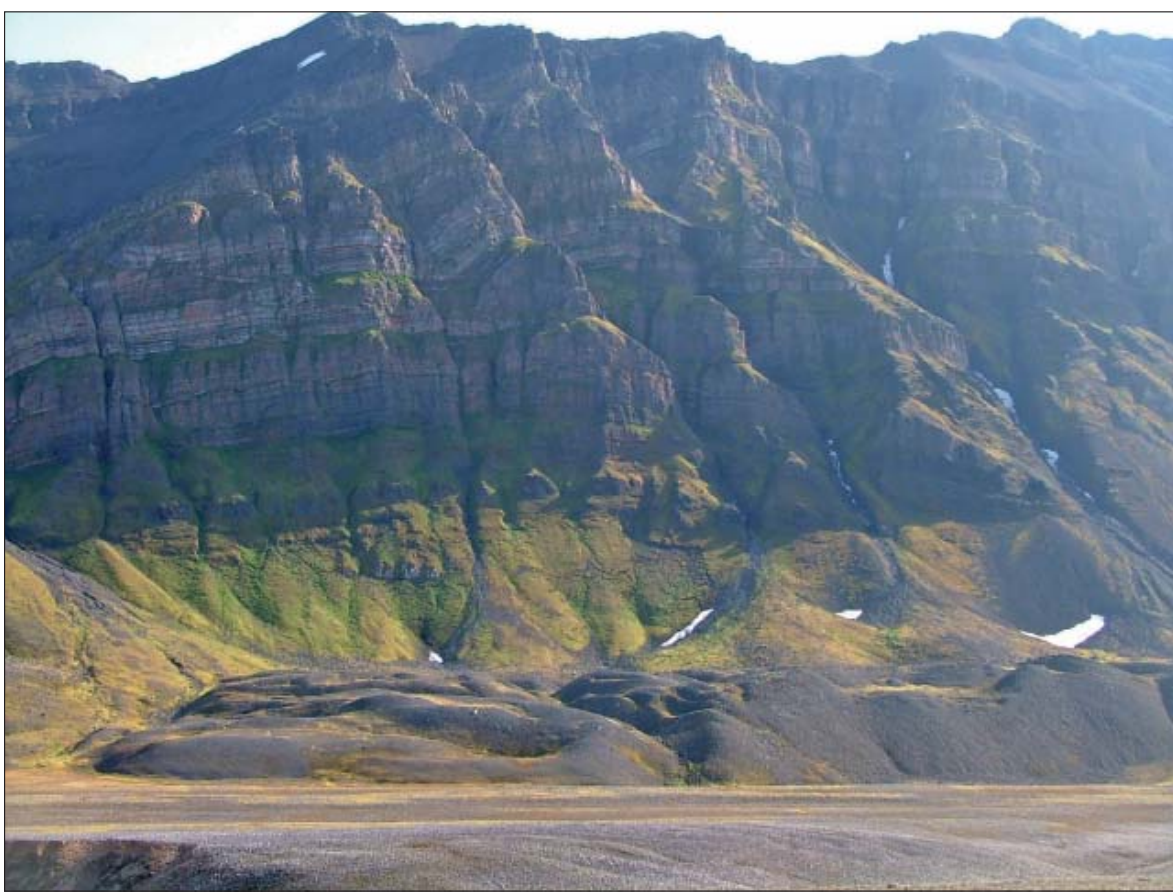

Blokgletscher neden for stejl fjeldbagvaeg ved Kapp Linné på det vestlige Svalbard. (Foto: Hanne H. Christiansen)

http://ipa.arcticportal.org/

IPY forskningsprosjektet Permafrost $\mathrm{Ob}$ servatory Project: A Contribution to the
Thermal State of Permafrost in Norway and Svalbard (TSP Norway): www.tspnorway. com

\section{Kort nyt}

Offentliggørelse af vand- og naturplaner Torsdag d. 14. januar offentliggjorde miljøminister Troels Lund Poulsen de længe ventede vand- og naturplaner, som han præsenterede som "den største satsning i Miljøministeriets historie". Vand- og naturplanerne er den konkrete udmøntning af målsætningerne i Grøn Vækst og heri beskrives mål og midler detaljeret for 23 vand-oplande og for 246 Natura 2000-områder (red: områder med særligt værdifuld natur i EU). Disse indsatsområder skal bl.a. sørge for, at Danmark lever op til EU's Vandramme-direktiv i 2015.

Helt Konkret skal vandplanerne reducere kvælstofudledningen til vandmiljøet og fosforindholdet i søerne, gøre $7.300 \mathrm{~km}$ vandløb til bedre levesteder for dyr og planter og sørge for spildevandsrensning fra alle i det åbne land. Endelig skal naturarealer plejes med græsning og bedre vandforhold. I forbindelse med Natura-2000-områderne skal tilbagegangen af dyre- og planteliv begrænses i de pågældende områder.

Man har længe ventet planerne i kommunerne - siden oktober 2008, hvor de skulle have været i høring - eftersom de danner grundlag for hele miljøarbejdet i kommunen - herunder planlægning af drikkevandsindvindingsplaner i fremtiden.

Det har dog lange udsigter, inden miljøarbejdet kan gå rigtigt $i$ gang - ifølge Ingeniørens overslag bliver det tidligst i 2012. Ministerens planer skal først i forhøring derefter i høring i seks måneder i kommunerne. Herefter skal ministeren kigge på indsigelserne, dernæst sende de endelige vandplaner ud, og til slut har kommunerne ét år til at lave handleplaner, som også indbefatter en høringsperiode.

Ing.dk/UVH

\section{Ny planet}

En ny planet, der har masser af vand og kun er få gange større end Jorden, er blevet opdaget af astronomer. Planeten benævnes foreløbig Superjord, fordi den er omkring fem gange større end Jorden.

Med stor sandsynlighed er der ikke liv på Superjord pga. den høje temperatur på omkring 200 grader, dog afviser David Charbonneau, professor i astronomi på Harvard University, ikke helt tanken, eftersom planeten ifølge professoren formentlig indeholder flydende væske.

Opdagelsen er blevet beskrevet som et stort gennembrud i jagten på liv i rummet.

$J P / S L J$

\section{Slumrende vulkan vågnet}

Vulkanen Turrialba i Costa Rica er vågnet efter næsten 125 års søvn. Den er begyndt at udsende aske og damp og bliver stadigt mere aktiv. 50 personer, der bor på flankerne, er blevet evakueret af myndighederne. 